Research Article

\title{
Antiapoptotic and antioxidant effects of resistance training with berberine consumption on diazinon induced cardiotoxicity in rats
}

\author{
Reza Niazi, Maghsoud Peeri*, Mohammad Ali Azarbayjani \\ Department of Exercise Physiology, Central Tehran Branch, Islamic Azad University, Tehran, Iran
}

\begin{tabular}{|c|c|}
\hline ARTICLE INFO & ABSTRACT \\
\hline $\begin{array}{l}\text { Keywords: } \\
\text { Antioxidant } \\
\text { Apoptosis } \\
\text { Berberine } \\
\text { Diazinon } \\
\text { Resistance training }\end{array}$ & 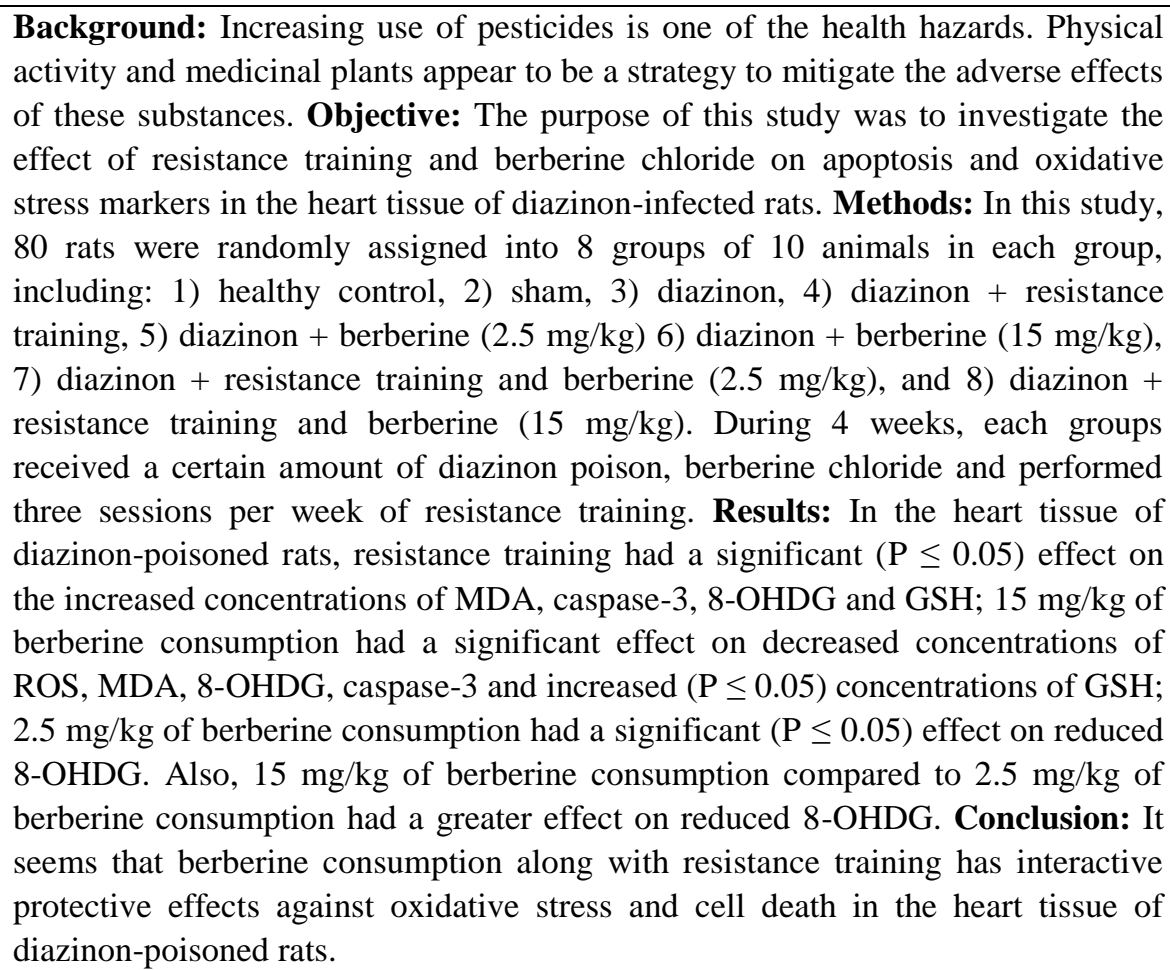 \\
\hline
\end{tabular}

\section{Introduction}

Different pesticides are used to cope with agricultural pests to increase crop production. Organophosphate pesticides are used as insecticides in the industry and agricultural farms. [1, 2]

Diazinon is the most important member among organophosphorus family that is

\footnotetext{
Abbreviations: (ROS) reactive oxygen species; (MDA) malondialdehyde

* Corresponding author: m.peeri@iauctb.ac.ir
}

doi: 10.29252/jmp.1.73.71

Received 1 June 2019; Received in revised form 2 June 2019; Accepted: 11 August 2019

(C) 2020. Open access. This article is distributed under the terms of the Creative Commons Attribution-NonCommercial 4.0 International License (https://creativecommons.org/licenses/by-nc/4.0/) 
absorbed through skin, digestive system and respiratory system, and is rapidly metabolized to diazooxone in the liver. The half-life of diazinon may last for more than a month in aerosol mineral soils, but is rapidly degraded in aquatic environments [6].

In the normal physiological state, some free radicals are produced via activity and metabolism of cells, which are neutralized by antioxidants in the body such as superoxide dismutase (SOD), catalase (CAT) and glutathione $(\mathrm{GSH})$. There is a balance between the two processes in the body. Therefore, any factor that disrupts this redox balance through high release of free radicals or reduction of antioxidants may result in oxidative stress, which consequently leads to pathological changes in the cell surface [3, 4].

Studies have shown that some organophosphates produce oxidative stress and peroxidation of lipids in mammals by producing free radicals $[1,5]$. On the other hand, the heart continuously performs blood supply to all tissues and organs. The heart muscle is unable to store oxygen for use, however, continuous oxygen and other nutrients must be provided for proper heart function. Moreover, the amount of antioxidant enzymes in heart tissues is less compared to other tissues. Therefore, the heart tissues are more susceptible to oxidative stress [13].

Increased sensitivity to oxidative stress in insulin resistance tends to reduce the expression of antioxidant enzymes in the tissues. In addition, the heart tissues particularly vulnerable to oxidative damage, have a larger oxidative capacity and relatively weak enzymatic capacity compared to other organs $[6,7]$.

It seems that the heart tissue is one of the organs affected by poisons with the mechanism of increasing cardiac apoptosis; hence, antioxidant foods consumption can delay the damage caused by the use of pesticides. In this regard, berberine is a plant alkaloid that has been used as a drug in the ancient Chinese, Indian, and Middle Eastern medicine due to its antimicrobial and anti-radiation properties. Berberine is an isoquinoline alkaloid which has anxiolytic, analgesic, anti-inflammatory, antimania, anti-depressant effects. Additionally, it has protective effects on memory [8].

Furthermore, Berberine has also been reported to have beneficial effects on functioning of the nervous system, and it can protect the neurons from various brain damage [10]. On the other hand, among different therapeutic ways to effectively cope with the side effects of cardiovascular injuries, physical activity is recommended as a multifactorial nonpharmacological remedy with no adverse effects.

It has now been widely recognized that an intense physical activity induces major homeostatic changes in the body's internal environment, which means it offers challenges to cells to survive under stress conditions [16]. On the other hand, increased mechanical and metabolic requirements through exercise in several organs and tissues, especially skeletal and cardiac muscles, may disrupt their homeostasis, thereby, increase the cellular damage or death, inflammation, and immunological changes in the blood $[17,18]$.

Now days, the potential value of resistance training in the field of development of health and fitness has been perceived [11]. Through recognizing the intensity and duration of exercise serve as an agent, that can modify apoptosis because increased apoptosis may cause excessive cell loss, affect the function of the tissues, and disrupt the process of tissue recovery.

The lack of research on the interactive effects of berberine consumption along with resistance training on the improvement of apoptosis and 
oxidative stress in the diazinon-poisoned conditions, this study aimed to investigate the effect of resistance training and berberine chloride on apoptosis and oxidative stress markers in the heart tissue of diazinon-infected rats.

\section{Materials and Methods}

\subsection{Animal}

In this experimental study, 80 male wistar rats weighing $250 \pm 50$ gr and 10-12 weeks' old were purchased from the Iran Pasteur Institute Center and transferred to the Animal Center of Iran University of Medical Sciences. To adapt to the environment, rats were kept under standard conditions of temperature $1\left(22 \pm 2{ }^{\circ} \mathrm{C}\right)$ and 12 hours of light / dark alternate cycles for one week. Then, animals were divided into 8 groups (10 in each group) including Healthy Control, Sham, Diazinon, Diazinon + Resistance Training (Diazinon + RT), Diazinon + Berberine $(2.5 \mathrm{mg} / \mathrm{kg})$ (Diazinon + $2.5 \mathrm{~B})$ Diazinon + Berberine $(15 \mathrm{mg} / \mathrm{kg})$ (Diazinon + 15 B), Diazinon + Resistance Training and Berberine $(2.5 \mathrm{mg} / \mathrm{kg}$ ) (Diazinon + RT + 2.5 B), and Diazinon + Resistance Training and Berberine (15 mg/kg) (Diazinon + RT + $15 \mathrm{~B})$.

\subsection{Diazinon injection}

The diazinon (manufactured by American Sigma Company code 454258-250MG) was diluted with $9 \%$ normal saline solution and was intraperitoneally injected at dose rat of $1.5 \mathrm{mg} / \mathrm{kg}$ in all groups; and berberine chloride (manufactured by American Sigma Company code B3251) was diluted with $9 \%$ normal saline solution and was peritoneally injected at given dose rat in all groups.

\subsection{Resistance training protocol}

Exercise groups rats performed resistance exercise training three times per week, while rats in control groups has no exercise activity. Resistance training included 3 sessions per week of climbing a vertical ladder (up to 1 meter on the 26th staircase) with a gradient of 80 degrees along with weightlifting. Each training session consisted of 2 sets with 6 repetitions, each requiring 8-12 active moves. The rest between each repetition was 60 seconds and between each set was 2-3 minutes. The training load started at $10 \%$ of the total body weight and reached $50 \%$ of body weight by end of protocol. The body weight of the rats was carefully measured at the start and end of each training week with a digital scale.

\subsection{Tissue collection}

All rats were anesthetized 48 hours after the last training session with intraperitoneal injection of ketamine $(100 \mathrm{mg} / \mathrm{kg})$ and xylazin $(10 \mathrm{mg} / \mathrm{kg})$. After complete anesthesia, perfusion was performed to remove blood from tissues. Heart tissues was removed, washed again, and kept in formalin until laboratory analysis.

\subsection{Tissue variable measurements}

Heart reactive oxygen species (ROS) (serial number CSB-EL020063RA), malondialdehyde (MDA) (serial number CSB-E08558r), GSH (serial number CSB-E12146r), caspase-3 (serial number CSB-E08857r) and 8-HydroxyDesoxyguanosine (serial number CSB-E10526r) was measured by the ELISA method using the American CUSABIO kit.

To investigate the histology of the heart, the heart tissues were isolated and washed with physiological serum and placed in the dishes with $10 \%$ formalin. The fixed samples were then embedded in paraffin wax. Serial sections were cut (5- $\mu \mathrm{m}$ thickness), stained with haematoxylin and eosin, and examined by using a light microscope (Olympus BX51; Olympus 
Co.). Masson's trichrome stain kit (Histogenotech Co., Iran), according to the manufacturer's instructions, to evaluate ventricular collagen fibers. Briefly, the section stain in Biebrich scarlet-acid fuchsin solution for 10-15 minutes. After washing the sample in distilled water, differentiate in phosphomolybdic-phosphotungstic acid solution for 10-15 minutes was done. The sections directly were transferred to aniline blue solution and stain for 5-10 minutes and then Rinsed in distilled water and differentiated in $1 \%$ acetic acid solution for 2-5 minutes. Dehydration very quickly was done through $95 \%$ ethyl alcohol, absolute ethyl alcohol, cleared in xylene and Mounted with resinous mounting medium. The collagen fibers will be stained blue and the nuclei will be stained black and the background is stained red. Image Tools Software (ver.3, Microsoft, Texas, USA) was used to measure the collagen deposition in five sections and four fields per section (an overall of 20 fields in each animal sample) were analyzed at magnification $\times 10$ of light microscopy. Photomicrographs were prepared.

\subsection{Data analyses}

Data were expressed as mean $\pm \mathrm{SD}$. The Shapiro-wilk test was used to determine the normality of data. The one-way and two-way ANOVA along with Bonferroni's post hoc test were used to determine the changes between groups. The changes consider as significant changes when $\mathrm{P}$ was $\leq 0.05$. All statistical analyses performed using SPSS software version 24.

\section{Results}

The results of one-way ANOVA showed a significant difference in the levels of ROS $(\mathrm{P}=0.001), \quad \mathrm{MDA} \quad(\mathrm{P}=0.001), \quad \mathrm{GSH}$ $(\mathrm{P}=0.001)$, caspase-3 $(\mathrm{P}=0.001)$, and 8 Hydroxy-Desoxyguanosine $(\mathrm{P}=0.001)$ in the heart tissue of rats in the healthy control, sham and diazinon groups.

The results of Bonferroni's post hoc test showed that ROS levels in the diazinon group were significantly higher than the healthy control and sham groups $(\mathrm{P}=0.001)$ (Fig. 1); also, there was no significant difference between the healthy control group and sham group ( $\mathrm{P}=0.07$ ) (Fig. 1); MDA levels in the diazinon group were significantly higher than the healthy control and sham groups $(\mathrm{P}=0.001)$ (Fig. 1). Also, there was no significant difference between the healthy control and sham groups ( $\mathrm{P}=$ 0.99) (Fig. 1); 8-OHDG levels in the diazinon group were significantly higher than the healthy control and sham groups $(\mathrm{P}=0.001)$ (Figure 1). There was no significant difference between the healthy control group and sham group $(\mathrm{P}=0.60)$ (Fig. 1); levels of caspase-3 in the diazinon group were significantly higher than the healthy control and sham groups $(\mathrm{P}=0.001)$ (Fig. 1). Meanwhile, there was no significant difference between the healthy control group and sham group $(\mathrm{P}=0.99)$ and GSH levels in the diazinon group were significantly lower than the healthy control and sham groups $(\mathrm{P}=0.001)$ (Fig. 1$)$. Also, there was no significant difference between the healthy control group and sham group $(\mathrm{P}=0.06)$ (Fig. 1).

The results of two-way ANOVA showed that resistance training had significant effect on increased MDA $(\mathrm{P}=0.001)$ and caspase-3 $(\mathrm{P}=$ $0.001)$ and decreased 8-OHDG $(\mathrm{P}=0.001)$, and GSH $(\mathrm{P}=0.001)$ levels in the heart tissue of diazine-poisoned rats (Fig. 1); yet it did not have a significant effect on ROS $(\mathrm{P}=0.40)$. Berberine consumption had a significant effect on decreased ROS $(\mathrm{P}=0.001)$, MDA $(\mathrm{P}=$ 0.001), 8-OHDG ( $\mathrm{P}=0.001)$, caspase-3 ( $\mathrm{P}=$ $0.001)$ and increased GSH $(\mathrm{P}=0.001)$ in the heart tissue of diazine-poisoned rats (Fig. 1). 

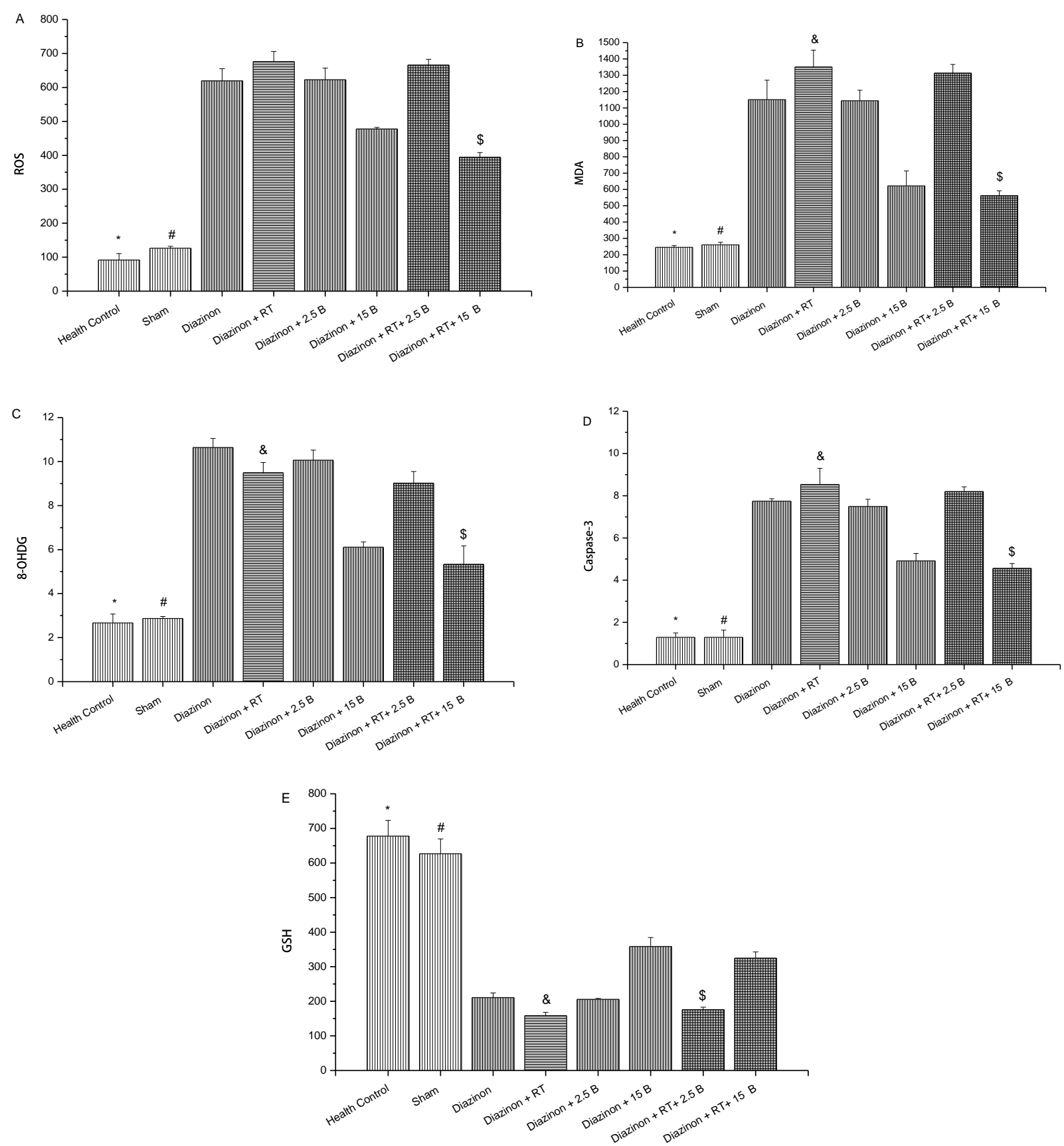

Fig. 1. Heart ROS (A), MDA (B), 8-OHDG (C), caspase-3 (D), GSH (E) concentration in different groups of study. The rats are 10 in each group. Data was expressed as mean \pm SD. The animal groups are Healthy Control, Sham, Diazinon, Diazinon + Resistance Training (Diazinon + RT), Diazinon + Berberine $(2.5 \mathrm{mg} / \mathrm{kg})($ Diazinon + 2.5 B) Diazinon + Berberine (15 mg / kg) (Diazinon + 15 B), Diazinon + Resistance Training and Berberine (2.5 mg / kg) (Diazinon + RT + $2.5 \mathrm{~B})$, and Diazinon + Resistance Training and Berberine (15 mg / kg) (Diazinon + RT + 15 B). 

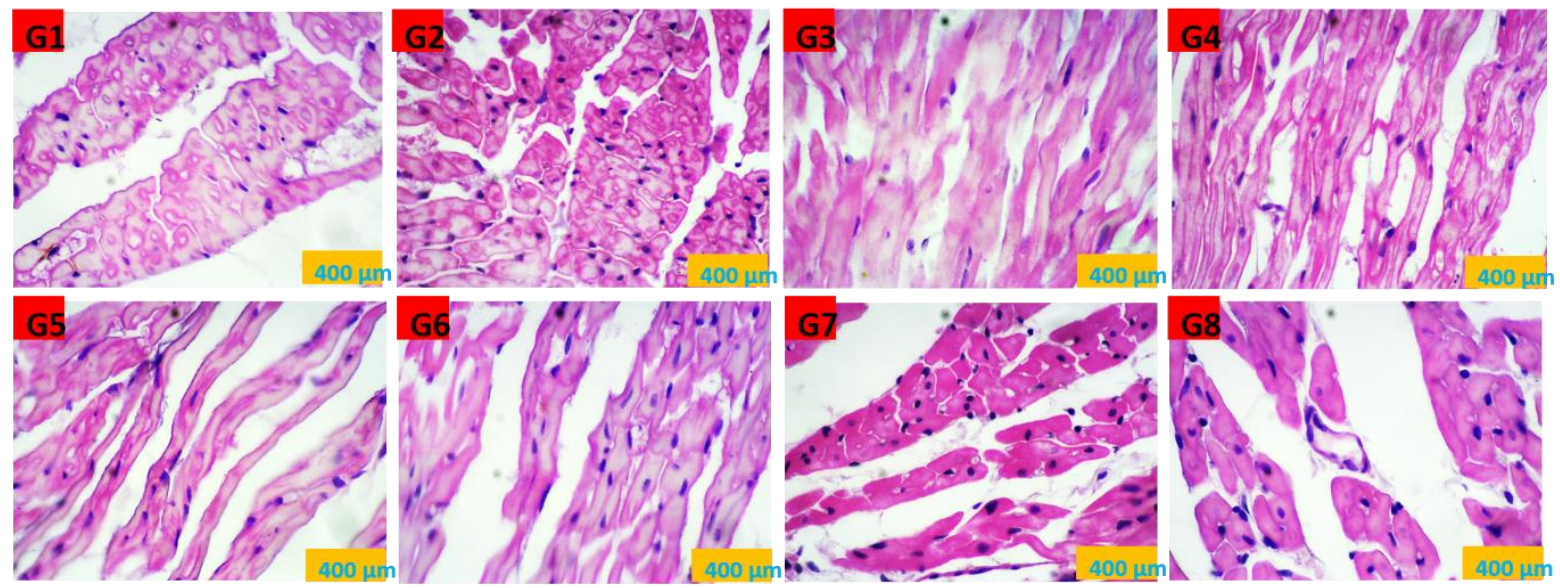

Fig. 2. Histological profile from heart tissue of rats. G1: diazinon + resistance training and $2.5 \mathrm{mg} / \mathrm{kg}$ of berberine group (damage up to about 75\%); G2) diazinon + resistance training and $15 \mathrm{mg} / \mathrm{kg}$ of berberine group (damage up to about 50\%); G3: diazinon group (damage greater than 75\%); G4: diazinon + resistance training group (damage up to about $75 \%$ ); G5: diazinon $+2.5 \mathrm{mg} / \mathrm{kg}$ of berberine (damage up to about $75 \%$; G6: diazinon $+15 \mathrm{mg} / \mathrm{kg}$ of berberine (damage up to about 75\%); G7: healthy control group (no damage to heart) and G8: sham group (no damage to heart).
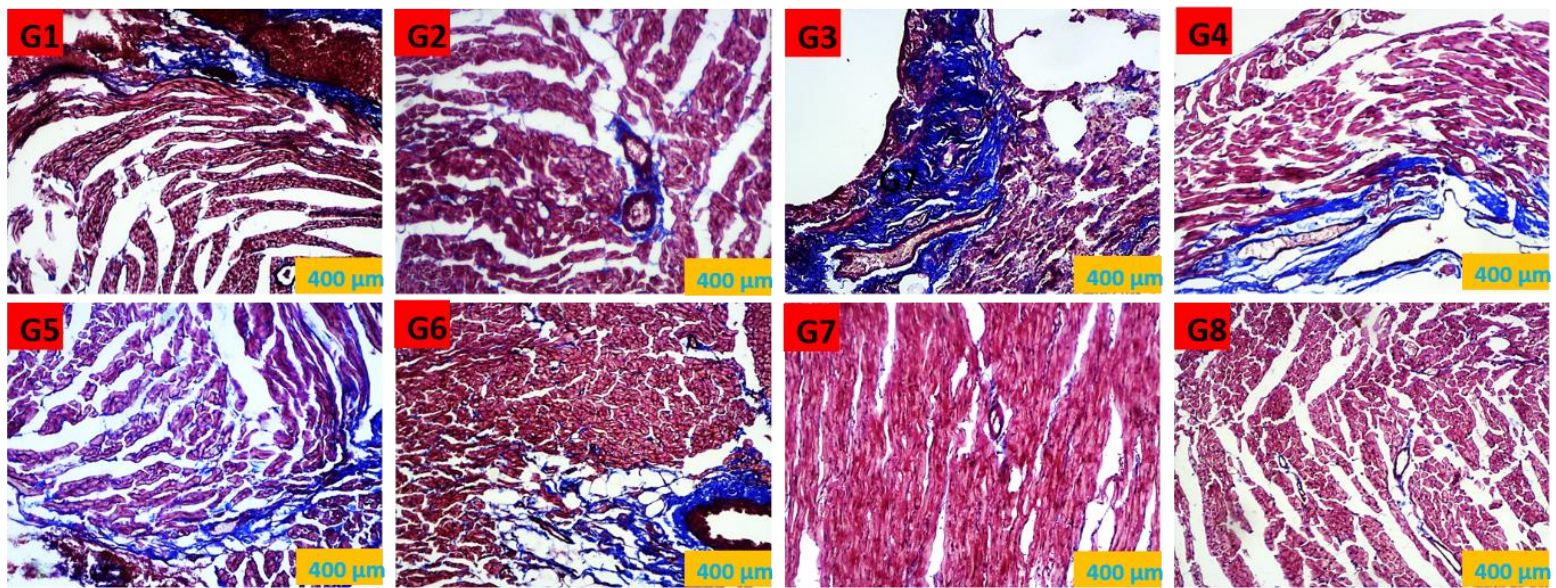

Fig. 3. Histopathological analysis of left ventricular (LV) tissue sections stained with Masson trichrome. Interstitial fibrosis with Masson trichrome stain were measured after 8 week from training in G1: diazinon + resistance training and $2.5 \mathrm{mg} / \mathrm{kg}$ of berberine group (damage up to about 30\%); G2) diazinon + resistance training and $15 \mathrm{mg} /$

$\mathrm{kg}$ of berberine group (damage up to about 20\%); G3: diazinon group (damage greater than 45\%); G4: diazinon + resistance training group (damage up to about $45 \%$ ); G5: diazinon $+2.5 \mathrm{mg} / \mathrm{kg}$ of berberine (damage up to about $55 \%$; G6: diazinon $+15 \mathrm{mg} / \mathrm{kg}$ of berberine (damage up to about $35 \%$ ); G7: healthy control group (no damage to heart) and

G8: sham group (no damage to heart). blue = fibrous collagen, and red = cardiomyocytes $200 \mathrm{X}$ magnification.

In addition, concurrent consumption of berberine along with resistance training had interactive effects on decreased $\operatorname{ROS}(\mathrm{P}=$ $0.001)$, MDA $(\mathrm{P}=0.001)$, caspase-3 $(\mathrm{P}=0.001)$ and increased GSH $(\mathrm{P}=0.04)$ in the heart tissue of rats poisoned with diazinon (Fig. 1).

The results of Bonferroni's post hoc test showed that in heart tissue of rats poisoned with diazinon, $15 \mathrm{mg} / \mathrm{kg}$ of berberine consumption had a significant effect on decreased ROS $(\mathrm{P}=$ 0.001), MDA ( $\mathrm{P}=0.001)$, 8-OHDG $(\mathrm{P}=0.001)$, caspase-3 $(\mathrm{P}=0.001)$ and increased GSH $(\mathrm{P}=$ $0.001) ; 2.5 \mathrm{mg} / \mathrm{kg}$ of berberine consumption had a significant effect on decreased 8-OHDG $(\mathrm{P}=0.008)$ (Fig. 1). However, there was no significant effect on $\operatorname{ROS}(\mathrm{P}=0.99)$, MDA $(\mathrm{P}=$ 
0.99), caspase-3 ( $\mathrm{P}=0.07)$, and GSH $(\mathrm{P}=0.59)$ (Fig. 1). Also, $15 \mathrm{mg} / \mathrm{kg}$ of berberine consumption compared to $2.5 \mathrm{mg} / \mathrm{kg}$ of berberine consumption had a greater effect on reduction of 8-OHDG $(\mathrm{P}=0.001)$ (Fig. 1).

The results of microscopic examination of tissue samples showed that cardio myocytes were not damaged in the healthy control and sham groups. However, in rats received diazinon, cardio myocytes were subjected to cell death. Cell death observed in the form of cellular partially vacuolated cytoplasm, fragmented cell nucleus, undisclosed nucleic membrane, lost cell membrane, and destroyed intercellular bindings.

The results showed that cardiomyocytes had the least damage in the diazinon + resistance training and $15 \mathrm{mg} / \mathrm{kg}$ berberine consumption (damage up to about 50\%) (Fig. 1b) and the highest cardiomyocyte damage was observed in the diazinon treated group (damage greater than $75 \%$ ) (Fig. 2c). Cardiomyocytes were also damaged in the diazinon + resistance training groups and 2.5 $\mathrm{mg} / \mathrm{kg}$ berberine consumption, diazinon + resistance training, diazinon $+2.5 \mathrm{mg} / \mathrm{kg}$ of berberine consumption and diazinon $+15 \mathrm{mg} / \mathrm{kg}$ of berberine up to about $75 \%$ (Fig. 2a, d, e, f, g, h).

Myocardial fibrotic remodeling, as reflected by trichrome staining of myocardial sections, was significantly more pronounced in the G3, when compared to $\mathrm{G} 7$ and $\mathrm{G} 8$ groups $(\mathrm{P}<0.05)$. This increase in G4 and G5 groups was lower than G3 group (Fig. 2). Semi-quantitative scoring of the staining showed a significant difference in LV fibrosis between the experimental groups (Fig. 3).

\section{Discussion}

In the present study, although resistance training did not have a significant effect on ROS, it has a significant effect on increase in
MDA, as well as reduction in 8-OHDG and GSH in the heart tissue of diazinon poisoned rats. Reported studies have suggested that the effects of regular exercise are beneficial. However, acute and intense sport activity through the activation of several pathways leads to the production of free radicals and ROS [39]. Increased ROS in the heart impairs endothelial function, decreases vascular dilatation and increases vascular contraction and, as a result, increases hypertension. [12] In this regard, increased production of free radicals, especially MDA, as one of the indicators of lipid peroxidation in the red blood cell membrane, following intense endurance exercise as reported previously $[13,14]$. In fact, MDA changes depend on the severity and duration of exercise, the amount of which after short and severe exercises increased [15], and conversely, after 9 months of regular exercise decreased [32].

Consistent with the findings of this research, 14 weeks of resistance training led to a significant reduction of 8-OHDG [43], therefore, participating in resistance training, increased strength and muscle hypertrophy, reduced oxidative stress and increased antioxidant enzymes activity [43]; thus, prolonged resistance training does not only seem to result in the deletion of the mitochondrial genome, but also reduces the amount of damage to the DNA of cell. Also, contrary to the findings of the present study, 6 weeks of resistance training can increase the levels of GSH irrespective of the severity of resistance training [51].

Given that resistance training has a recovery interval between movements and exercises between each course, the long recovery period of 30-90 seconds in low-intensity exercises with high volumes and a long-term recovery time of 2-5 minutes in the high and low intensity 
resistance training can be effective in generating responses and ultimately possible adaptations.

It seems that part of the mechanism of exercise activity in reducing oxidative stress relates to other protective mechanisms of exercise, including increased neurotrophic factors, including the brain-derived neutrophic factor (BDNF) and the relative improvement of cerebral blood flow during ischemia.

In the present study, resistance training had a significant effect on increased levels of caspase- 3 in the heart tissue of diazinon-poisoned rats. In line with the findings of the present study, it was reported that sport activity, especially severe and eccentric, led to an increase in the cell death [16-18].

The type of exercise activity can be an important factor in the changes in apoptotic indices; in this vein, Bax gene expression and Bax to $\mathrm{Bcl} 2$ ratio, which is one of the caspase- 3 production factors, was reported to reduce in the rats running for 12 weeks on the treadmill compared to the control group [19].

One of the effects of sports activities is the increase of mitochondrial biogenesis, which can play an important role in the pathway of causing agents and thus preventing apoptosis [20]. Also, the results of this study showed that $15 \mathrm{mg} / \mathrm{kg}$ of berberine consumption had a significant effect on decreased ROS, MDA, 8-OHDG and caspase-3, and increased GSH; and $2.5 \mathrm{mg} / \mathrm{kg}$ of berberine consumption had a significant effect on reduction of 8-OHDG. Besides, 15 $\mathrm{mg} / \mathrm{kg}$ of berberine consumption compared to $2.5 \mathrm{mg} / \mathrm{kg}$ of berberine consumption had a greater effect on the reduction of 8-OHDG. Furthermore, $150 \mathrm{mg} / \mathrm{kg}$ of berberine consumption has a significant effect on reducing MDA and also decreases pathologic changes in diabetic rats [21]; leads to improvement of cardiac disturbances [38], and improves apoptosis process [47].
It has also been shown that berberine consumption increases GSH, which can cope with excess free radicals and overcome oxidative stress [52, 53].

According to the findings of this study, it seems that the anti-oxidative and apoptotic effects of berberine consumption are dose dependent, so that in present study, the use of $15 \mathrm{mg} / \mathrm{kg}$ of berberine had a greater effect than $2.5 \mathrm{mg} / \mathrm{kg}$ of berberine. It has been argued that berberine can act as an indirect antioxidant and direct detoxifying agent in the cell. Also, berberine directly neutralizes a variety of oxidative species and protects cells from oxidative damage by stimulating the synthesis of SOD and promoting the activity of various antioxidant enzymes, including CAT and GSH-Px [22].

Moreover, Berberine can easily cross the brain-blood barrier and after transferring to nerve cells, is slowly eliminated, which shows a direct effect of it on nerve cells in different areas of the brain, including the cortex. Although the precise neuro-protective mechanism of berberine is not well defined, [23]. In this regard, the results of the examination of tissue samples showed that 2.5 $\mathrm{mg} / \mathrm{kg}$ and $15 \mathrm{mg} / \mathrm{kg}$ consumption of berberine reduced the pathological damage in the heart tissue of diazinon poisoned rats.

Concerning the interactive effects in the present study, concurrent consumption of berberine along with resistance training had interactive effects in reducing ROS, MDA, caspase-3 and GSH. The production of reactive oxygen species (ROSs) is increased during high intensity exercise through involvement of active muscle cell mitochondria [24]. Nonetheless, in the present study, resistance training alone did not have a significant effect on reduction of ROS, berberine consumption along with resistance training had a decreasing effect on ROS, which can be 
attributed to the beneficial effects of berberine and may be associated with affecting the pathways for the production of free radicals in special physiological conditions in specific tissues. Consumption of berberine helps to repair DNA damage to proteins and lipids by the production of antioxidants.

In sum, protein damage by reactive oxygen species in natural environments or exposure to toxins affects the function of receptors, enzymes and transfection proteins, and is also involved in secondary degradation of other biomolecules by deactivating defensive antioxidants enzymes and regenerative enzymes [27, 28].

Examination of tissue samples showed that cardio myocytes had the least damage with 15 $\mathrm{mg} / \mathrm{kg}$ barbrin consumption with resistance training group (damage up to 50\%). In the group receiving $2.5 \mathrm{mg} / \mathrm{kg}$ berberine with resistance training, the damage to cardio myocytes was about 75 percent. Therefore, it seems that the interactive effect of berberine consumption and resistance training isdose dependent, so that consumption of berberine with a higher dose has more protective effects on the heart tissue of diazinon poisoned rats than the lower dose.

\section{Conclusion}

In this study, although diazinon poisoning led to an increase in oxidative stress and apoptosis markers and cardio myocyte damage, berberine consumption along with resistance training had interactive effects against oxidative stress and cell death in the heart tissue of rats poisoned

\section{References}

1. Storm JE, Rozman KK and Doull J Occupational exposure limits for 30 organophosphate pesticides based on inhibition of red blood cell acetylcholinesterase. Toxicol. 2000; 150: 1-29.

Journal of Medicinal Plants with diazinon; therefore, these findings strongly suggest that berberine consumption along with resistance training has protective effect under oxidative pressure conditions by increasing the antioxidant enzyme activity and by decreasing the peroxidation of lipids.

Therefore, berberine consumption along with resistance training can be implemented as an effective agent for controlling oxidative stress and protecting DNA cell.

\section{Author contributions}

All authors equally contributed to the writing and revision of this paper.

\section{Conflict of interest}

The authors declare that they have no conflict of interest.

\section{Ethical Considerations}

Researchers received introduction letters from Sport Sciences Research Institute of Iran with ethics code IR.SSRI.REC.1397.38

\section{Acknowledgements}

Considering the fact that the present study is a part of the doctoral dissertation approved by Central Tehran Branch of Islamic Azad University, the authors of this article express their gratitude and appreciation for the spiritual support of the Research and Technology Department of this university branch.

\section{Abdollahi M, Mostafalou S,} Pournourmohammadi $S$ and Shadnia S. Oxidative stress and cholinesterase inhibition in saliva and plasma of rats following subchronic exposure to malathion. Comparative Biochemistry and Physiology Part C: Toxicology \& Pharmacol. 2004; 137: 29-34. 
3. McCord JM. The evolution of free radicals and oxidative stress. The American J. Medicine 2000; 108: 652-659.

4. Matés JM, Pérez-Gómez C and De Castro IN. Antioxidant enzymes and human diseases. Clinical Biochem. 1999; 32: 595-603

5. Saulsbury MD, Heyliger SO, Wang $K$ and Johnson DJ. Chlorpyrifos induces oxidative stress in oligodendrocyte progenitor cells. Toxicol. 2009; 259: 1-9.

6. Busserolles J, Zimowska W, Rock E, Rayssiguier $\mathrm{Y}$ and Mazur A. Rats fed a high sucrose diet have altered heart antioxidant enzyme activity and gene expression. Life Sciences 2002; 71: 1303-1312.

7. Morrison JA, Jacobsen DW, Sprecher DL, Robinson K, Khoury P and Daniels SR. Serum glutathione in adolescent males predicts parental coronary heart disease. Circulation 1999; 100: 2244-2247.

8. Ghani E, Mohammadi M, Jafari M, Khoshbaten A and Asgari A. Evaluation of oxidative stress index in brain tissue of rats after expose to paraoxon. Kowsar Medical J. 2008; 13: 1-7.

9. Kaur R and Sandhu H. In vivo changes in antioxidant system and protective role of selenium in chlorpyrifos-induced subchronic toxicity in bubalus bubalis. Environmental Toxicology and Pharmacol. 2008; 26: 45-48.

10. Khan SM, Sobti R and Kataria L. Pesticideinduced alteration in mice hepato-oxidative status and protective effects of black tea extract. Clinica Chimica Acta 2005; 358: 131-138.

11. Malekyian-Fini E, Kaviani-Nia $A$ and Mahmoudi F. The interactive effect of aerobic training and resveratrol supplementation on $\mathrm{C}$ reactive protein and metabolic profiles in women with type 2 diabetes. Feyz Journal of Kashan University of Medical Sciences 2015; 19 (5): 372381.
12. Yamamoto $\mathrm{K}$, Kondo $\mathrm{T}$, Kimata $\mathrm{A}$, Ueyama J, Shirotori A, Okada Y, Sakui D, Nakashima M and Yamada S. Lack of effect of aerobic physical exercise on endotheliumderived nitric oxide concentrations in healthy young subjects. Nagoya J. Medical Science 2007; 69: 167.

13. Mcbride JM and Kraemer WJ. Free Radicals, Exercise, and Antioxidants. The Journal of Strength \& Conditioning Res. 1999; 13: 175-183.

14. Radak Z, Asano K, Inoue M, Kizaki T, OhIshi S, Suzuki K, Taniguchi $\mathrm{N}$ and Ohno $\mathrm{H}$. Superoxide dismutase derivative reduces oxidative damage in skeletal muscle of rats during exhaustive exercise. J. Applied Physiol. 1995; 79: 129-135.

15. Lovlin R, Cottle W, Pyke I, Kavanagh M and Belcastro A. Are indices of free radical damage related to exercise intensity. European J. Applied Physiology and Occupational Physiol. 1987; 56: 313-316.

16. Krüger $\mathrm{K}$ and Mooren FC. Exerciseinduced leukocyte apoptosis. Exercise Immunology Review 2014; 20: 117-34.

17. Quadrilatero J, Alway SE and DupontVersteegden EE. Skeletal muscle apoptotic response to physical activity: potential mechanisms for protection. Applied Physiology, Nutrition and Metabolism 2011; 36: 608-617.

18. Phaneuf $S$ and Leeuwenburgh C. Apoptosis and exercise. Medicine \& Science in Sports \& Exercise 2001; 33: 393-396.

19. Jafari A, Pourrazi H, Nikookheslat $S$ and Baradaran B. Effect of exercise training on Bcl2 and bax gene expression in the rat heart. Gene, Cell and Tissue 2015; 2 (4): e60174.

20. Kordi MR, Nekouei A, Shafiee A and Hadidi V. The effect of eight weeks high intensity aerobic continuous and interval training on gene expression of vascular 
endothelial growth factor in soleus muscle of healthy male rats. Arak Medical University J. 2015; 18: 53-62.

21. Zhou J, Zhou S, Tang J, Zhang K, Guang L, Huang Y, Xu Y, Ying Y, Zhang L and Li D. Protective effect of berberine on beta cells in streptozotocin-and high-carbohydrate/high-fat diet-induced diabetic rats. European $J$. Pharmacol. 2009; 606: 262-268.

22. Singh $J$ and Kakkar P. Antihyperglycemic and antioxidant effect of Berberis aristata root extract and its role in regulating carbohydrate metabolism in diabetic rats. J. Ethnopharmacol. 2009; 123: 22-26.

23. Ju H, Li X, Zhao B, Han $Z$ and Xin W. Scavenging effect of berbamine on active oxygen radicals in phorbol ester-stimulated human polymorphonuclear leukocytes. Biochemical Pharmacol; 1990; 39: 1673-1678.

24. Margaritis I, Palazzetti S, Rousseau A-S, Richard M-J and Favier A. Antioxidant supplementation and tapering exercise improve exercise-induced antioxidant response. $J$. the American College of Nutrition 2003; 22: $147-$ 156.

How to cite this article: Niazi R, Peeri M, Azarbayjani MA. Antiapoptotic and antioxidant effects of resistance training with berberine consumption on diazinon induced cardiotoxicity in rats. Journal of Medicinal Plants 2020; 19(73): 71-81.

doi: $10.29252 / \mathrm{jmp} .1 .73 .71$ 
فصلنامه كياهان دارويي

فصلنامه گياهان دارويى

مقاله تحقيقاتى

اثرات ضد آيويتوزى و آنتىاكسيدانى تمرين مقاومتى با بربرين كلرايد بر سميت سلول هاى قلبى ناشى از ديازينون در موش صحرايى رضا نيازى، مقصود بيرى"، محمد على آذربايجانى كروه فيزيولوثى ورزشى، دانشكاه آزاد /سلامى واحل تهران مركزى، تهران، ايران

\begin{tabular}{|c|c|}
\hline جكيده & اطلاعات مقاله \\
\hline مقدمه: افزايش استفاده از آفتكشها يكى از خطرات تهديدكننده سلامتى مىباشد. فعاليتهاى بدنى و & 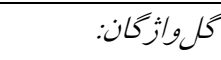 \\
\hline كياهان دارويى به عنوان يكى راهكار سودمند براى كاهش اثرات اين مواد توصيه شدهاند. هدف: هدف از & آنتى اكسيدان \\
\hline اجراى اين مطالعه، بررسى اثر تمرين مقاومتى و بربرين كلرايد بر نشانگران آيويتوز و فشار اكسيداتيو بافت & آيويتوز \\
\hline قلب رت هاى مسموم شده با ديازينون بود. روش بررسى: در اين مطالعه •^مر رت نر به صورت تصادفى & 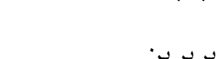 \\
\hline به هشت گروه ده تايى شامل كتترل سالم، شم، ديازينون، ديازينون تمرين مقاومتى، ديازينون Y/Q ميلى گرم & 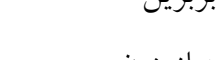 \\
\hline بربرين به ازاى هر كيلوكرم از وزن بدن، ديازينون ها ميلى گرم بربرين به ازاى هركيلوكرم وزن بدن، & ديازينون \\
\hline ديازينون تمرين مقاومتى T/ه ميلى گرم بربرين به ازاى هر كيلوكرم از وزن بدن و ديازينون تمرين مقاومتى & 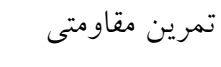 \\
\hline ها ميلى گرم بربرين به ازاى هر كيلو گرم وزن بدن تقسيم شدند. طى جهار هفته هر كروه ديازينون و بربرين & \\
\hline كلرايدرا دريافت نموده و هفتهاى سه جلسه تمرين مقاومتى انجام دادند. نتايج: در بافت قلب موشهاى & \\
\hline صحرايى مسموم با ديازينون، تمرين مقاومتى اثر معنىدارى در كاهش غلظت افزايش يافته MDA، كاسياز & \\
\hline 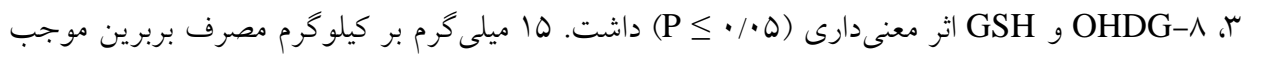 & \\
\hline كاهش معنى دار غلظت ROS، MDA ، 8-OHDG و كاسياز r شد، اما غلظت GSH را افزايش داد & \\
\hline 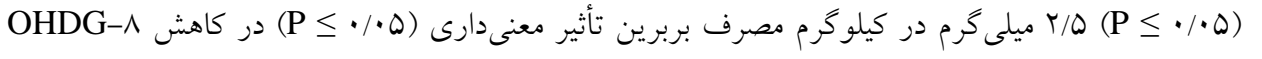 & \\
\hline داشت. همجنين، 10 ميلى گرم بربرين كلرايد به ازاى هر كيلو گرم وزن بدن در مقايسه با Y/D ميلى گرم به & \\
\hline ازاى هر كيلوكرم وزن بدن اثر بيشترى در كاهش OHDG-ᄉ داشت. نتيجه گيرى: به نظر مىرسد مصرف & \\
\hline بربرين همراه با تمرين مقاومتى داراى اثرات محافظتى در برابر استرس اكسيداتيو و مرگ سلولى در بافت & \\
\hline قلب موشهاى مسموم با ديازينون دارد. & \\
\hline
\end{tabular}

مخغفنها: مان m.peeri@iauctb.ac.ir نويسنده مسؤول: doi: 10.29252/jmp.1.73.71

(C) 2020. Open access. This article is distributed under the terms of the Creative Commons Attribution-NonCommercial 4.0 International License (https://creativecommons.org/licenses/by-nc/4.0/) 